\title{
Preface: the central role of zooplankton in freshwaters, a special issue in honour of late Ramesh D. Gulati
}

\author{
S. S. S. Sarma · S. Nandini · H. J. Dumont $\cdot$ Brij Gopal
}

Published online: 4 October 2021

(C) The Author(s), under exclusive licence to Springer Nature B.V. 2021

The present volume is dedicated to the memory of late Ramesh D. Gulati, born on the 28th of September 1935, in Piplan (at the time in undivided India). After obtaining his doctoral degree in limnology (1964, University of Delhi) and after teaching for a few years at the same university, he wrote to Dr. Han Golterman, at that time the leading limnologist of the Netherlands. He asked for a job, and Golterman, who had a nose for talent, invited RD Gulati to come over; his wife, Toshi, joined him a couple of years later. He made significant contributions in the areas of zooplankton-phytoplankton interactions, nutrient dynamics and stoichiometry and was a pioneer in biomanipulation and lake

Brij Gopal was deceased.

S. S. S. Sarma $(\bowtie) \cdot$ S. Nandini

Laboratoy of Aquatic Zoology, National Autonomous

University of Mexico, FES Iztacala, 54090 Tlalnepantla,

$\mathrm{CP}$, Mexico

e-mail: sarma@unam.mx

\section{H. J. Dumont}

Department of Ecology, Jinan University, Guangzhou, China

\section{H. J. Dumont}

Department of Biology, University of Gent, Gent, Belgium

B. Gopal

Centre for Inland Waters in South Asia Vill., Peera,

Khajuraho, MP, India restoration. He passed away on 23 December 2019 after a short illness at his hometown, Hilversum in the Netherlands (for details see Gopal et al. 2020).

Dr. Gulati was the former Editor in Chief of Aquatic Ecology (1996-2015). He dedicated more than 60 years of research to limnology in general and plankton ecology, in particular. His contributions to the ecology of zooplankton helped us improve our understanding of the central role of rotifers, cladocerans and copepods in the plankton community structure of freshwater ecosystems. Two of us (SSSS and SN) were fortunate to meet him at his home just a few days before his demise.

Soon after Dr. Gulati's death, it was planned to bring out a special volume in his honour. Aquatic Ecology readily accepted to bring out this special issue, for which we thank Dr. Télesphore SimeNgando, Editor in Chief and Ms. Victoria Ferrara and Mrs. Judith Terpos of Springer. We agreed to function as guest editors for the special issue based on our personal and professional contact with Dr. Gulati for decades. The theme of the special issue, The Central Role of Zooplankton in Freshwaters, was decided considering the significant contributions made by Dr. Gulati in this area. In June 2020, we sent invitations to selected researchers for possible contributions to the special issue. The processing of the manuscripts was shared by all the four guest editors and the Editor in Chief. As in the case of regular issues, not every contribution was accepted for publication. Only those 
strongly recommended for publication were sent to the Editor in Chief for a final decision. In all 18 works were selected for publication in the special issue. However, two of them have been allocated to a regular issue (Vol. 55, Issue 2: Braun et al. 2021, Leoni et al. 2021) but are still discussed here due to their relevance to this special issue. The special issue contains 16 full length contributions.

There was a delay because one of the guest editors, Dr. Brij Gopal, passed away on 4 January 2021 (see Finlayson 2021). His last manuscript, On the role of macrophytes in structuring zooplankton communities, remains unfinished. However, Brij Gopal's name has been retained as guest editor posthumously.

The work by Duggan et al. (2021) on long-term (about 12 years) limnological studies on the Waikato region lakes (New Zealand) documents the occurrence of two non-native zooplankton species, the Australian Boeckella symmetrica and the Holarctic Daphnia galeata in the New Zealand. Their study also considers the trophic state of the chosen waterbodies. For example, Synchaeta longipes, Ascomorpha saltans, A. ovalis, Conochilus coenobasis, Epiphanes macrourus and Ceriodaphnia dubia positively associated with low trophic state, while Proales cf. monopus, Brachionus caudatus, B. quadridentatus, Keratella tecta and $K$. tropica negatively correlated with high trophic state.

Muñoz-Colmenares et al. (2021) review the role of zooplankton in freshwater ecosystems as indicators of water quality and productivity. Based on more than 300 zooplankton samples and the corresponding variables obtained for a decade, these authors were able to classify the studied waterbodies into good (99 reservoirs), moderate (202) and poor (3) following the European Water Framework Directive.

Diel vertical migration by zooplankton is a behavioural adaptation, well documented in many aquatic habitats. While there are many reasons for this behaviour, the most commonly attributed factors include escape from predation, avoiding ultraviolet radiation, exploiting food resources, etc. (reviewed in Bandara et al. 2021). Reverse vertical migration by zooplankton is also known, especially to avoid competitors such as Streptocephalus or to escape from non-visual predators such as Asplanchna (Dumont 2019). In the present issue, Sha et al. (2021) sampled copepods from six blue holes located on Andros Island (The Bahamas) at six depths (from 1 to $5 \mathrm{~m}$ ). The data were analysed using weighted mean depth (WMD). The results show that daytime WMD of calanoid copepods was positively associated with the predation risk. In addition, the authors also observed significant correlations between the weighted mean calanoid depth and the weighted mean chlorophyll $a(\mathrm{Chl} a$ ) depth. Two contributions (Bernatowicz et al. 2021a, b) address similar behavioural aspects using Daphnia. One of the articles describes the selection of depth in the water column by five clones of $D$. longispina, $D$. galeata and their hybrids, while the second contribution measures developmental noise in depth selection behaviour and body size of parental and hybrid clones from D. galeata, D. hyalina and the hybrids exposed to fish kairomones, non-toxic cyanobacterial (Cylindrospermopsis raciborskii) filaments and polychlorinated biphenyls.

Three contributions on the tropical cladoceran Diaphanosoma deal with two important aspects of ecology of this genus. Liu et al. (2021) have carefully analysed the genetics of $D$. dubium using microsatellite markers with next-generation sequencing. Their results suggest higher genetic diversity within $D$. dubium during summer months. Further, their results confirm the fact that resting eggs in Cladocera promote genetic diversity in large water bodies, especially during summer months. The second contribution on Diaphanosoma by Dumont et al. (2019) has considered the phylogeny and zoogeographical distribution of this genus. There are three parts in this contribution: 1. Based on the morphological traits of exopodite of P6, the authors identified species-specific differences in nine species of Diaphanosoma. 2. Using patterns of geographical distribution of Diaphanosoma, Dumont et al. (op. cit.) claim the existence of unsubstantiated records of $D$. brachyurum and deep evolution within $D$. sarsi in the tropics leading to the conclusion of hidden biological diversity under the guise of uniform morphology. 3. Phylogeny of Diaphanosoma reveals the existence of significant genetic distance between two clades, hexa and hepta, that are now allocated to Neodiaphanosoma and Diaphanosoma s.s., respectively.

Nandini et al. (2017) have studied the starvation resistance time, bacterivory and demography of Diaphanosoma mongolianum under laboratory conditions. D. mongolianum survived up to 5 days under total starvation. Using two different strains (A: constantly exposed to toxic Microcystis and M: not 
exposed to cyanobacteria) of D. mongolianum, the authors report that both strains were able to survive and reproduce on diets of Microcystis. Based on population growth studies using different fractions of lake seston $(0-15 \mu \mathrm{m})$, the authors show that $D$. mongolianum can feed on a wide range of diets including bacterioplankton and phytoplankton.

Zooplankton species have been used as indicators of water quality for many decades. For example, Sládeček's (1983) ratio of Brachionus to Trichocerca $\left(\mathrm{Q}_{\mathrm{B} / \mathrm{T}}\right)$ is widely used to classify the trophic state of waterbodies. Yet, much remains to be studied mainly because of global changes in the environment and the availability of new tools to identify species to infraspecific levels correctly. Though rotifers and cladocerans receive considerable attention as indicators of water quality, copepods, especially calanoids, are also sensitive to changes in the medium. The work by Min et al. (2021) in this issue fulfils some aspects of this using copepod biomass as indicators of eutrophication. Based on historical data of about 17 years on zooplankton and chosen physico-chemical parameters, including nutrient concentrations and $\mathrm{Chl} a$ levels from 68 Danish lakes, the authors observed that when the lake $\mathrm{pH}$ was acid $(<6.0)$ calanoids were dominant in the copepod zooplankton community. On the other hand, in shallow lakes, with an increase in $\mathrm{pH}(>6)$, the calanoid biomass decreased with increasing phosphorus and Chl $a$ levels. It appears that calanoid biomass is a good indicator of trophic state especially in shallow waterbodies with low $\mathrm{pH}$.

Two contributions present quantitative data on the role of fish in zooplankton structure. Since the classic works of Hrbacek (1962) and Brooks and Dodson (1965), food selectivity studies show that fish feed on large prey items and shift the zooplankton composition towards small-bodied taxa. Brancelj (2021) studies changes in the species composition of rotifers, cladocerans and copepods due to fish stocking in Slovenian lakes located on the limestone bedrock. During the observational period (1991-2012), largebodied copepods and cladocerans were eliminated by fish leading to proliferation of small-bodied zooplankton along with benthic species, associated with algal mats. Yağc1 et al. (2021) study the gut contents of three fish species, viz. pike-perch, Sander lucioperca, bigscale sand smelt, Atherina boyeri and top-mouth gudgeon Pseudorasbora parva all of which are nonnative to Turkish inland waters. Their results showed significant differences in the prey selection by the three fish species. For example, the dominant prey items of big-scale sand smelt and top-mouth gudgeon were zooplankton, while that of the pike-perch was other fish species.

Zooplankton body size and shape may help animals to escape or deter predation; the effect differs depending on both prey type and predator species. In the presence of vertebrate predators, rotifer prey often reduce their body size as so to make them energetically unprofitable. On the other hand, invertebrate predators being unable to handle large items, prey develop defensive structures so as to minimize being caught. Fish predation often leads to reduction in the biomass of zooplankton species. However, Braun et al. (2021) argue that zooplankton size distribution is possibly a more suitable method to understand topdown and bottom-up effects than the zooplankton biomass. Based on the data collected from a waterbody in Germany, Lake Stechlin, these authors show that the overall zooplankton size distribution is not significantly affected by fish predation, but their study reports negative correlations between fish biomass and preferred zooplankton prey.

The effect of climate change on zooplankton has been gaining importance in both marine (Richardson 2008) and freshwater ecology (Vadadi-Fülöp et al., 2012). Leoni et al. (2021) in their study attempt to reconstruct the subfossil cladoceran species distribution and density from an Italian waterbody, Lake Iseo in relation to climate and anthropogenic stresses. Based on their large dataset, the authors suggest that climatic factors and nutrient availability hold the key in controlling the temporal development of the plankton community structure in Lake Iseo.

Four contributions present data on different aspects of rotifer ecology. Ejsmont-Karabin and Karpowicz (2021) report qualitative and quantitative data on the structure and diversity of rotifer species from different sub-habitats of Polish lakes from 2009 to 2020. Using long lists of well-identified rotifer species from the lake sub-habitats, the authors state that species richness was lower in pelagic waters than in the region with aquatic vegetation. Keratella cochlearis was dominant in the pelagic region of most waterbodies. In the epiphyton, the authors encountered Lecane closterocerca and L. lunaris with highest frequency. Lecane closterocerca occurred as an epizoic on bivalve molluscs and this rotifer species was also 
most dominant in the hydropsammon region. Further, the authors discuss species richness and habitat heterogeneity in the studied waterbodies. Wallace et al. (2021) report the benthic rotifer community structure based on an extensive literature survey. The authors report more than 415 benthic rotifer species. By re-examining the data on benthic rotifer species presented by Ejsmont-Karabin (2003), these authors conclude that the trophic state does not affect the composition of trophi types among the benthic rotifers. However, species richness decreases with increasing trophic state index, as Ejsmont-Karabin (2003) earlier reported. In addition, the authors provide a detailed account of the gaps in our understanding of community composition and function of benthic rotifer species.

Culturing rotifers belonging to different genera is helpful, not only to understand the life history strategies of rotifers, but also useful in other areas such as phylogenetic analysis, aquaculture and ecotoxicology. Outside Brachionidae only a few genera of rotifers from the families such as Euchlanidae, Proalidae, Notommatidae and Lecanidae have been successfully cultured. In this volume, Nandini and Sarma (2021) obtain densities of Dipleuchanis propatula, isolated from a tropical river, as high as 50 ind. $\mathrm{ml}^{-1}$ when fed Chlorella diet at a concentration of $1.0 \times 10^{6}$ cells $\mathrm{ml}^{-1}$. The data on the life table parameters show that the mean survival time of $D$. propatula was similar to other members of the family Euchlanidae to which this species belongs. When cultured together, Paramecium and $D$. propatula have mutually adverse effects on their population growth rates. The fourth contribution on the rotifer ecology is authored by Zhou et al. (2021). These authors present data on the stoichiometric aspects of the rotifer Brachionus calyciflorus. The role of nutritional quality and stoichiometry in plankton is an important aspect in aquatic ecology, as advocated by R.D. Gulati (Gulati and DeMott 1997). Zhou et al. (op. cit.) in this work cultured B. calyciflorus fed the green alga Chlamydomonas reinhardtii grown under contrasting C:P ratios using different combinations of nutrient and light conditions. Their data show that the growth rates of rotifers were significantly affected by algal C:P ratio and the growth history of the algae.

Bdelloid rotifers, tardigrades and nematodes share the unique feature of anhydrobiosis or cryptobiosis. Bhakare and Pai (2021) present a study on the diversity, distribution and ecology of tardigrades from the Western Ghats of India based on a 6-year study. They found more than $80 \%$ of the tardigrades in temporary freshwater ponds with $\mathrm{pH}$ usually in the alkaline range. Further, the authors also state that tardigrades frequently co-occur with rotifers and nematodes.

The various studies included in this special issue represent many aspects of the role of zooplankton in aquatic ecosystems. It is offered to the scientific community with the hope that it may serve as tribute to the work and scientific legacy of our good friend, the regretted Ramesh D. Gulati.

\section{References}

Bandara K, Varpe $\varnothing$, Wijewardene L, Tverberg V, Eiane K (2021) Two hundred years of zooplankton vertical migration research. Biol Rev 96:1547-1589. https://doi.org/10. 1111/brv. 12715

Brooks JL, Dodson SI (1965) Predation, body Size, and composition of plankton: the effect of a marine planktivore on lake plankton illustrates theory of size, competition, and predation. Science 150(3692):28-35. https://doi.org/10. 1126/science. 150.3692 .28

Dumont HJ (2019) Zooplankton vertical migration in two Sahara lakes with contrasting biotic environments. Limnetica 38(1):95-101. https://doi.org/10.23818/limn.38.08

Ejsmont-Karabin J (2003) Rotifera of lake psammon: community structure versus trophic state of lake waters. Polish J Ecol 51:5-35

Finlayson M (2021) Remembering Dr. Brij Gopal. Society of Wetland Scientists. January issue. https://www.sws.org/ 2021/01/21/remembering-dr-brij-gopal/

Gopal B, Sarma SSS, Nandini S (2020) Obituary. Fifty years of research on plankton ecology, biomanipulation and restoration of shallow lakes in the Netherlands: a tribute to Dr. Ramesh Datt Gulati (1935-2019). Hydrobiologia 847(17):3511-3517

Gulati R, DeMott W (1997) The role of food quality for zooplankton: remarks on the state-of-the-art, perspectives and priorities. Freshw Biol 38:753-768. https://doi.org/10. 1046/j.1365-2427.1997.00275.x

Hrbacek J (1962) Species composition and the amount of zooplankton in relation to the fish stock. Rozpravy Československé Akademie Věd: Řada Matematických 72:1-117

Nandini S, Sarma SSS, Gulati RD (2017) A seasonal study reveals the occurrence of exotic rotifers in the river Antigua, Veracruz, close to the Gulf of Mexico. River Res Appl 33(6):970-982

Richardson AJ (2008) In hot water: zooplankton and climate change. ICES J Mar Sci 65:279-295 
Sládeček V (1983) Rotifers as indicators of water quality. Hydrobiologia 100:169-201. https://doi.org/10.1007/ BF00027429

Vadadi-Fülöp C, Sipkay C, Mészáros G, Hufnagel L (2012) Climate change and freshwater zooplankton: what does it boil down to? Aquat Ecol 46:501-519. https://doi.org/10. 1007/s10452-012-9418-8
Publisher's Note Springer Nature remains neutral with regard to jurisdictional claims in published maps and institutional affiliations. 